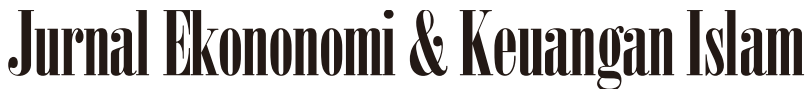

\author{
Available at http://journal.uii.ac.id/index.php/jeki
}

\section{Role of the development of Islamic finance to financial inclusion: empirical study in Islamic banking countries}

\author{
Priyonggo Suseno ${ }^{1)}$, Yeny Fitriyani ${ }^{2)}$ \\ ${ }^{1}$ Universitas Islam Indonesia, Yogyakarta, Indonesia \\ ${ }^{2}$ STAI Al-Husain SW Magelang, Indonesia \\ *Corresponding author email: priyonggo@uii.ac.id
}

\section{Keywords:}

Random Effect Model (REM), Financial Inclusion, the Development of Islamic Finance.

DOI:

\begin{abstract}
The purpose of this paper is to determine the level of financial inclusion in OIC countries which operate Islamic Banking and the link between financial inclusion and the development of Islamic finance. This study investigates the role of Islamic finance to financial inclusion which included the development of Islamic financial and socio-economic variables as independent variable. Panel data regression has been used to estimate the relationship between the development of Islamic finance and financial inclusion. EGLS, Estimated Generalize Least Square, is conducted to reduce the autocorrelation among residual due to cross-sectional effect. Using Sharma Financial Inclusion Index, this study finds that the average Financial Inclusion Index, IFI, is 22.2 with the highest index is 56.7 for Kuwait and the lowest index is 2.8 for Sudan. Using the three non-standard Random Effect Model (REM) models, this research generates consistent and robust regression coefficients. This research found that there is a negative impact of development of Islamic finance on financial inclusion, even small. This indicates that the development of Islamic finance does not help much the public to increase access to the financial sector. On the other hand, financial inclusion is still heavily influenced by macroeconomic variables such as the level of unemployment and national income.
\end{abstract}

\begin{abstract}
Abstrak
Tujuan penelitian ini adalah untuk mengukur tingkat inklusi keuangan di negara-negara anggoto Organisasi Kerjasama Islam, OKI, yang mengoperasikan perbankan syariah serta hubungan antara inklusi keuangan dengan pengembangan keuangan Islam. Penelitian ini membahas peran keuangan Islam terhadap inklusi keuangan dengan memasukkan variable perkembangan keuangan Islam dan variabel ekonomi sosial sebagai variabel penjelas. Regresi data panel digunakan untuk mengestimasi hubungan antara pengembangan keuangan Islam dan inklusi keuangan. EGLS, Estimated Generalize Least Square, digunakan untuk mengurangi potensi adanya autokorelasi akibat adanya efek antar ruang (cross-section). Dengan merujuk indeks inklusi keuangan Sharma, studi ini menemukan bahwa indeksi Inklusi keuangan rata-rata di negara-negara OKI adalah 22,2 dengan indeks tertinggi adalah 56,7 untuk Kuwait dan indeks terendah adalah 2,8 untuk Sudan. Dengan menggunakan tiga model non standar Random Effect Model (REM), riset ini menunjukkan hasil yang konsisten dan robust. Riset ini menemukan bahwa pengembangan keuangan Islam terhadap inklusi keuangan, cenderung memberikan kontribusi negatif meskipun kecil. Hal ini mengindikasikan bahwa pengembangan keuangan Islam tidak banyak membantu masyarakat untuk meningkatkan akses kepada sektor keuangan. Di sisi lain, inklusi keuangan masih banyak dipengaruhi oleh variable ekonomi makro seperti tingkat pengangguran dan pendapatan nasional.
\end{abstract}

\section{Introduction}

Islamic finance assets grew at double-digit rates during the past decade, from about US\$200 billion in 2003 to an estimated US\$2.1 trillion at the end of 2014, witnessing a 1000 percent over ten years (IMF, 2015). However, despite its growing spread, the share of Islamic finance to the global financial asset is still low, less than 1 percent and is still concentrated in the Gulf Cooperation Council (GCC) countries, Iran and Malaysia.

According to some Muslim scholars, Islamic finance has the potential to encourage inclusive finance. According to Mohieldin et al (2012), Islamic finance has strong pillar concerning on social justice, inclusion, and sharing of resources between the have and have not. Islamic finance tackles the issue of financial exclusion from two directions - one through promoting risk sharing contracts and through specific instruments of redistribution of the wealth among the society, such as zakah, waqf and qard al hasan. (Demirguc-kunt \& Klapper, 2013).

Unfortunately, the fact showed that most Muslim countries have lower level of financial inclusion level, either in term of macro perspective or micro perspective. It can be shown shortly that most Organization of 
Islamic Cooperation (OIC) countries have low level of financial inclusion even though they have experienced rapid economic growth and financial expansion during the past decade (Mohieldin et al 2012). For example, they have experienced of lower level of micro-finance outreach, such as the values of microfinance institutions (MFI) deposits and loans as percentage of GDP are still much lower in OIC countries $(0.61 \%$ and $0.79 \%)$ compared with developing countries $(0.78 \%$ and $0.97 \%)$ and low income countries $(0.92 \%$ and $1.19 \%)$. In line with that finding, the Global Findex Report 2014 showed that most of populous Muslim countries, especially Indonesia, Pakistan, Bangladesh and Nigeria, have 30 percent lower financial inclusion indicators than that of the average of the developing countries.

This paper focuses on two main objectives. The first objective is to find out the role of the development of Islamic finance to financial inclusion in Islamic banking countries, OIC countries which operate Islamic banking system. It would also answer the question of which factors determines financial inclusion in Islamic banking countries.

\section{Literature Review}

Most of the recent literatures on the subject financial inclusion and its empowerment came from the conventional perspective, where are commonly discussed as two different subjects. One subject focuses on financial inclusion and the process of empowerment, while the others focuses on the impact of financial inclusion on economic growth and poverty alleviation (Ascarya et.al, 2015).

In Islamic perspective and studies, the subjects of financial inclusion have been discussed on some literatures under two main views. Most views investigate the financial inclusion level in Muslim societies and its determinants that incorporates specific variables taken from the Islamic perspective such as zakah, qard al-hasan financing or Islamic microfinance, such as being done by Midgley, (2005), Mohieldin et al (2012), Naceur, et al (2015), Demirguc-Kuntet et al (2013) and Zulkhibri (2016). However, they still used the mainstream approach to measure financial inclusion level, due to their interest to compare between Muslim and Non-Muslim countries or lack of data availability. On the other hand, few researches tried to develop an Islamic perspective on financial inclusion and they tested empirically in Muslim countries, which include Warsame (2009), Mohieldin, et al. (2012), Iqbal and Mirakhor (2012 and 2013), Iqbal (2014), and Ascarya et al. (2015).

Focusing the relationship and role of Islamic finance to financial inclusion, some literatures provided similar conclusion even though each has stressed on certain aspect. Some literature examines a potential of Islamic finance as a whole to enhance financial inclusion, such as Mohieldin et al (2012), Iqbal and Mirakhor (2012 and 2013), Sain (2013), and Iqbal (2014). Meanwhile some literatures observed specific Islamic finance and its relationship to financial inclusion. Kahf (2002) and Ahmad (2004) proposed establishing a Microfinance Institutions based on zakah and waqf. Fasih (2013) and Naceur (2015) examined the role of Islamic bank to financial inclusion. In addition, Dabla-norris et al (2015) examine to role of commercial bank, in general, to financial inclusion.

Starting from general view, Mohieldin et al (2012) examined a potential of Islamic finance to enhance the financial inclusion. They proposed two main elements of Islamic instruments. The first element is risksharing contracts which are reflected as Islamic microfinance services, such as micro financing, micro insurance, micro savings, and small-micro enterprises (SME). Second type of instruments is redistributive instruments such as zakah, sadaqah, waqf, and qard al-hasan which have been offering a comprehensive approach to poverty alleviation. Based on 20 OIC country members, they found the evidence that domestic zakah could alleviate the poorest society with income under US $\$ 1.25$ per day. Since then, Mohieldin et al (2012) has recommended the role of Islamic microfinance and redistributive instruments as a comprehensive framework of financial inclusion, which have been supported with the use of advance technology and sound regulatory and supervisory framework financial engineering in order to support microfinance and micro enterprises.

In line with Mohieldin et al (2012), Iqbal and Mirakhor (2012 and 2013) discussed and confirmed that financial inclusion in Islamic perspective comprises of Islamic financial instruments and Islamic redistributive instruments both based on risk-sharing. They concluded that Islamic finance provides a comprehensive framework of financial inclusion through the principle of risk-sharing and through Islam's redistributive channels which are grossly under-utilized in Muslim countries. Likewise, Iqbal (2014) also discussed an Islamic perspective on financial inclusion and addressed the issue of financial inclusion from two directions, namely risk sharing and specific instruments of redistribution of the wealth among the society. He emphasized that the low income people needed more comprehensive approaches to financial inclusion that could be undertaken through hybrid solutions to prepare them as micro and small enterprises.

Naceur et al (2015) examined more comprehensively the relationship between the development of Islamic banking and financial inclusion in OIC countries. He found that various indicators of financial inclusion tend to be lower in OIC member countries, and the share of excluded individuals due to religious reasons for not using bank accounts is greater than in non-OIC countries. 


\section{Theoretical Framework and Hypothesis Development}

\section{Definition and dimension of financial inclusion}

Initially, financial inclusion was defined as the ability to access necessary financial services in an appropriate form, low-cost, fair and safe financial products and services from mainstream providers (United Nations, 2007). The operational definitions have also been evolved from the underlying public policy concerning many people living on low income, who cannot access mainstream financial products such as bank accounts and low cost loans, which, in turn, imposes real costs on them — often the most vulnerable people (Treasury, 2004). Therefore, over the past decade, financial inclusion has entered into the social policy glossary of many developed and developing countries (Zuleika, 2010). Thus, access to financial services or outreach of the financial system has become a major concern for many policy makers in developing countries (Beck and Torre, 2006).

Financial inclusion could be generalized as the process of ensuring access and use of financial products and services to all class of the society and vulnerable groups such as weaker classes, minorities and low income groups at the affordable cost in a fair and transparent manner by regulated main institutional players (World Bank, 2014). This includes having ability, capacity, skill, knowledge and understanding to make the best use of those products and services. Thus, the scope or dimensions of financial inclusion includes all range of financial services and products of formal and modern financial institutions existed in a country. To simplify the measurement complexity, Sharma $(2008,2010,2012)$ categorized the dimension to be three main aspects, which are financial access, financial products and services and financial usage.

\section{The causes of financial exclusion}

Financial exclusion, the opposite term of financial inclusion, refers to the inability of individuals to access, and or effectively use and take benefit of financial products which can help them to improve their social life and well being (European Commission, 2008; World Bank, 2014). Why some society being excluded from formal financial institutions is very difficult to pick out one particular reason. Financial exclusion could be divided into two types, which are voluntary self-exclusion or involuntary exclusion. Voluntary exclusion means there could be cultural or religious reasons for not using financial services such prohibition of interest-based financing in Islamic faith. The later type of financial exclusion is originated from the supply side. Financial institutions, such as commercial banks, were viewed as being proactive prefers to do exclusive finance in order to manage risk, reduce costs and improve their company value. The financial institution, mainly the bank, was seen as holding the main market power. By holding this power, they were supposed to be able to downgrade or exclude groups whom they considered to be a bad risk to outside areas or namely unbanked groups. Therefore, reducing the level of involuntary financial exclusion is the major agenda of financial inclusion policy (Kodan and Chikara, 2013).

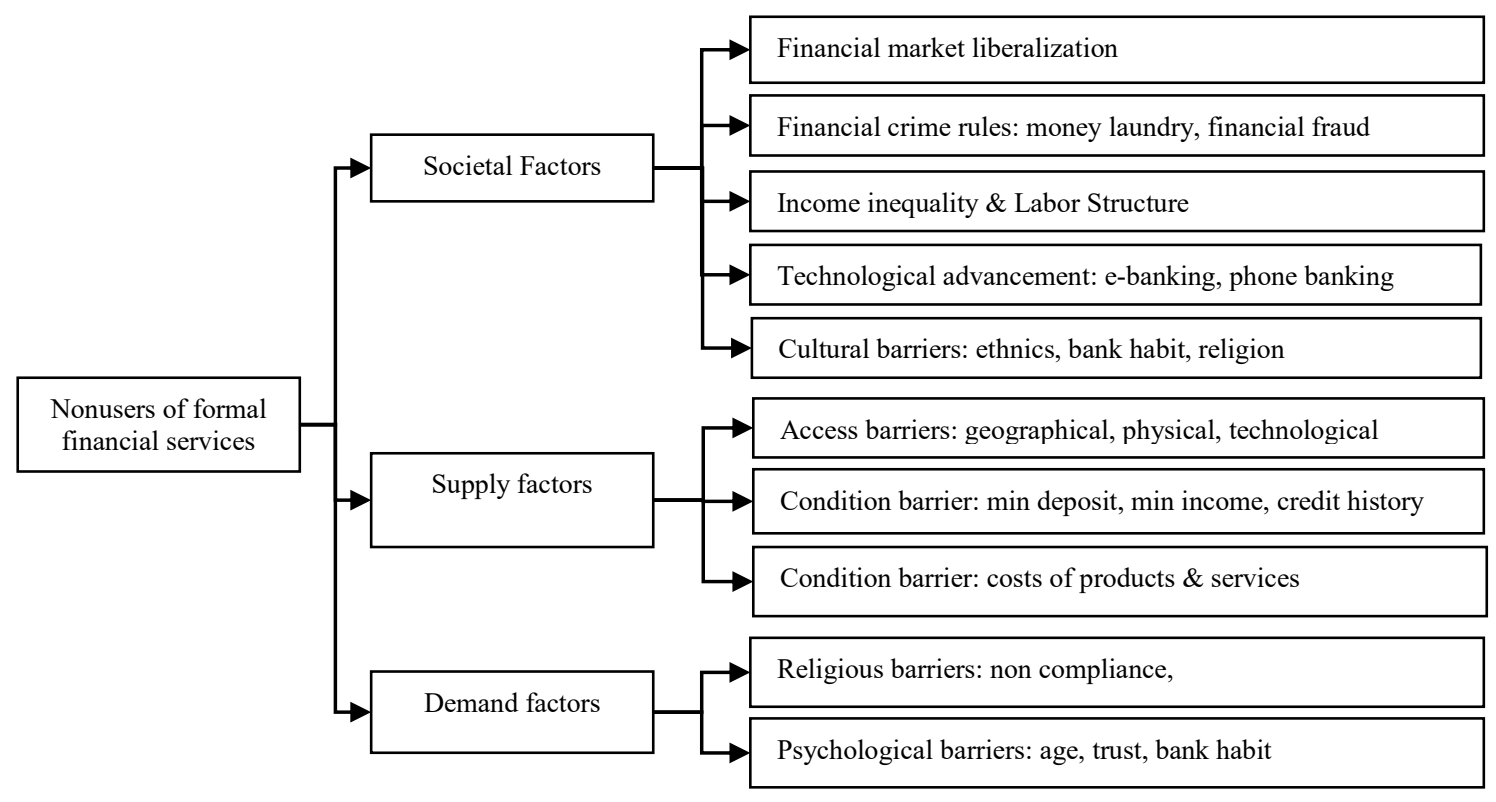

Figure 1. Type and Causes of Financial Exclusion 


\section{Hypothesis Development}

Based on the above reviews, this paper focuses on Islamic banking countries as being defined by Naceur et al (2015). There are two main hypotheses will be investigated:

1) The role of the development of Islamic finance to financial inclusion in Islamic banking countries is small but significant.

2) Societal factor dominate the influence of the development of Islamic finance to financial inclusion.

\section{Research Method}

\section{Key Variables}

Based on the above two main objectives, the variables will be divided to be two which is endogenous and exogenous variables. This paper adopts revised financial inclusion index initiated by Sharma (2008, 2010 and 2012) in determining the financial inclusion index, incorporate various banking sector variables to reflect the level of accessibility, availability and usage of banking services. But this paper limits on the macro-level based index due to the lack of data at regional level. The exogenous variable being used in this paper are also the macro-level data that being adapted from Kumar (2013).

Following Sharma (2010), the index considers three basic dimensions, i.e. banking penetration (BP), availability of the banking services (BS) and usage of the banking system (BU). These dimensions are largely motivated by availability of relevant and consistent data for a large number of countries to compute Financial Inclusion Index (FII). Banking penetration (BP) reflects of how many users have been penetrated by banking system. The size of the "banked"e population could be the best measure of the banking penetration of the system. However, because of data unavailability, we use number of bank accounts as a proportion of the total adult population as an indicator of this dimension. For the second dimension, availability of Islamic banking services, we use banking outlets (offices, branches, banking personnel, ATM and so on). In the present index, we use data on the number of Islamic bank branches and the number of ATMs per 100,000 populations to measure the availability dimension. Two separate indexes are calculated for bank branches and ATMs with weight, using $2 / 3^{\text {rd }}$ weight for bank branch index and $1 / 3^{\text {rd }}$ weight for ATM index. The third dimension is measured with two basic services of the banking system - credit and deposit in proportion of the country's GDP with the weight of $1 / 3$ and $2 / 3$ respectively. The formula of the IFI index is:

$$
I F I=\frac{\sqrt{\sum_{i=1}^{3}\left(w_{i}-d_{i}\right)^{2}}}{\sqrt{\sum_{i=1}^{3} w_{i}^{2}}}=\frac{\sqrt{\left(1-d_{1}\right)^{2}+\left(0.3-d_{2}\right)^{2}+\left(0.7-d_{3}\right)^{2}+\left(0.7-d_{4}\right)^{2}+\left(0.3-d_{5}\right)^{2}}}{\sqrt{1^{2}+0.3^{2}+0.7^{2}+0.3^{2}+0.7^{2}}}
$$

We use gap value $\left(\mathrm{d}_{\mathrm{i}}\right)$ in order to normalize the data and reduce the potential bias to size of the economy. We use four classifications of the inclusiveness level as being used by Kainth (2013):

1) $0.66<$ IFI $\leq 1-$ Very high financial inclusion

2) $0.50 \leq$ IFI $<0.66$ - high financial inclusion

3) $0.30 \leq$ IFI $<0.50$ - medium financial inclusion

4) $0 \leq$ IFI $<0.30-$ low financial inclusion

The independent variables will be divided into two categories: socio non-economic variables and supply factors. Socio non-economic variables refers to financial, economic and social development features which in this paper will be measured by the economic prosperity or GDP per capita (lnGDP), unemployment level (UR), corruption level (CPI) and technological advancement (TECT) which being reflected with the availability of internet banking system in the country. We use corruption perception index to reflect the accountability of financial system. For supply factors, we use Islamic Finance Country Index (IFCI). We do not use the variables that are unique to Islamic banks, risk sharing and social-based financing, as used by Warsame (2009) and Kunt et al. (2012), because of limited access to the data at the micro level.

\section{Data Collection}

Data is needed to empirically verify the proposed model as questioned in the first and the second hypothesis. We include only Islamic banking countries, as defined by Naceur (2015), which comprise of 37 countries which have the bank operating under Islamic principles. However, not all countries currently have CPI and the ICFI, so that the number of countries studied entirely only to 29 countries. Some data are collected from the Bank scope 
and some from FSA-IMF, the World Bank, Islamic Finance Country Report (IFCR) and www.transparancy.org. All data are cross sectional among countries which based on the report on the year of 2015 . Few missed data on unemployment level is completed using data from tradingeconomic.com.

\section{Methods of Estimation}

In order to investigate the determinant of financial inclusion, we utilize panel regression. Due to peculiarities of the pooled dataset, observations for the individual may not be independent and usual ordinary least squares method may provide biased estimates. Hence, we employ panel data estimation techniques (fixed-effects model and random-effects model) to control for fixed or random individual differences. Hausman test has been applied to test for appropriateness of fixed or random effects model (REM). However, to minimize heteroscedastic effect on cross-sectional data we utilized a generalise least square estimation such as seemingly unrelated regression (SUR) model and estimated GLS.

To estimate the magnitude of each influence, this research utilizes a panel data regression model:

$F I I_{i t}=\alpha_{i}+\beta_{1} C P I_{i t}+\beta_{2} U R_{i t}+\beta_{3} \ln G D P_{i t}+\beta_{4} I C F I_{i t}+\beta_{5} T E C H_{i t}+\varepsilon_{i t}$

\section{Research Findings}

\section{Financial inclusion description on IB countries}

In general, the financial index of IB countries is low, 0.22 , but it varies among countries. The country with the third highest FII is Kuwait, Brunei and Tunisia with FII is $0.57,0.48$, and 0.48 respectively. While, some countries have very low level of FII, closed to zero, such as Afghanistan and Sudan.

If we look in more detail, of the three aspects of the FII, financial access (BA) has the lowest level compared to the world average. IB countries on average have access to banks is 2.63 times lower than the world average, which if measured by the number of 1,000 adults who have accounts in banks. Banking access for the IB countries is 422 on average, while the average world has reached 1110 . That means that average of the adult population of the world have more than one bank account.

On the other hand, in term of banking services (BS), most IB countries have lower level compared with the world level. Number of ATM on IB countries is 1.25 times lower than that of the world average. However, the number of banking branches in IB countries is large enough compared with the world level. This indicates some countries may have limited branches and ATM network, especially in African countries such as Senegal, The Gambia and Kenya. Some countries develop few banks with many ATM networks, such as Indonesia, Malaysia, Uni Arab Emirates, Turkey, Qatar, and Kazakhstan.

The third indicator of FII, financial or banking usage (BU), shows that IB countries experiences little much higher than the world average. The outstanding deposits and loans over the GDP of IB countries constitute, 57.68 and 43.75 respectively, while the outstanding deposits and loans over the GDP of world average constitute, 49.59 and 44.37 respectively.

Table 2. Financial Inclusion Index on Islamic Banking Countries

\begin{tabular}{cccccccc}
\hline No & \multicolumn{1}{c}{ Country } & FII & Rank & No & \multicolumn{1}{c}{ Country } & FII & Rank \\
\hline 1 & Afghanistan & 0.04 & 27 & 16 & Malaysia & 0.35 & 6 \\
2 & Algeria & 0.12 & 22 & 17 & Mauritius & 0.15 & 19 \\
3 & Azerbaijan & 0.24 & 13 & 18 & Nigeria & 0.24 & 12 \\
4 & Bahrain & & & 19 & Oman & 0.16 & 18 \\
5 & Bangladesh & 0.28 & 10 & 20 & Pakistan & 0.22 & 14 \\
6 & Brunei & 0.48 & 2 & 21 & Qatar & 0.32 & 8 \\
7 & Egypt & 0.20 & 15 & 22 & Saudi Arabia & 0.30 & 9 \\
8 & Gambia & 0.12 & 21 & 23 & Senegal & 0.08 & 24 \\
9 & Indonesia & 0.18 & 16 & 24 & Sudan & 0.03 & 29 \\
10 & Iran & 0.25 & 11 & 25 & Syria & 0.10 & 23 \\
11 & Jordan & 0.16 & 17 & 26 & Tunisia & 0.43 & 3 \\
12 & Kazakhstan & 0.05 & 25 & 27 & Turkey & 0.34 & 7 \\
13 & Kenya & 0.35 & 5 & 28 & United Arab Emirates & 0.13 & 20 \\
14 & Kuwait & 0.57 & 1 & 29 & Yemen & 0.04 & 28 \\
15 & Lebanon & 0.41 & 4 & & & & \\
\hline
\end{tabular}




\section{Research Finding and Discussion}

From 50 countries which operate Islamic banking on various levels, only 29 countries provide enough data, especially for socio non-economic variables such as corruption level and unemployment level for period 2011 to 2015. Based on the available data, Fixed Effect Model (FEM) and Random Effect Model (REM) are estimated and we evaluate them using Hausman test to identify which one generate more efficient estimators.

Hausman test for both models, FEM and REM, showed the inconsistent results which give suggestion to follow random effect model but with low goodness of fit. This suggests to run other test, which Lagrange Multiplier (LM) test such as Breusch-Pagan test (BP). This test suggests choosing random effect model, because cross-section effect is proven significant (with BP statistic is 190.2027), while time-series effect is trivial (with BP statistic is 2.4693).

The result will summarise four estimated models, which are the REM standard model, three generalises least square (GLS) in estimating coefficient covariance. The First model is GLS with cross-section weight in order to reduce cross-sectional heteroscedasticity effect. The second model is Cross-section SUR generalized least squares which is also GLS estimator for systems where the residuals are both cross-sectionally heteroskedastic and contemporaneously correlated. The third is White cross-section method which assumes that the errors are contemporaneously (cross-sectionally) correlated (a period clustered). According to the last three models, the results show that one variable does not have significant role to financial inclusion which is CPI, three variables have significant roles and one variable is inconsistent.

Not all societal factor have significant impact on financial inclusion. Macroeconomics factors, such as the level of prosperity (GDP per capita) and employment level have a positive relationship with financial inclusion. The higher the prosperous population, the higher the level of financial inclusion is. Similarly, the higher the unemployment level of a country, the lower the level of financial Inclusion will be. This condition indicates that economic development tends to help financial inclusion rather than financial development perse the government of some countries have engaged to support financial inclusion since last decade with various economic programs and poverty alleviation.

But law factor, which is measured by the level of corruption perception, does not have any significant effect on financial inclusion according to all methods. However, most IB countries experience high level of corruption, whose CPI average is 3.63 (out of 10) and there are only four IB countries with CPI higher than 5.0 which are Qatar, Mauritius, Brunei and United Emirate Arab. This indicates that people perception on corruption level does not associate with their involvement to financial system.

Other societal factor is technological advancement, which is measured by the use of mobile money transaction. In general, mobile money technology has been utilised worlds widely. In 2015, more than 4.43 billion people already use mobile phone and estimated will grow to 4.77 billion in 2017 (www.statista.com). However, this development does not support too much to financial inclusion level.

Table 3. Panel Regression Coefficients

\begin{tabular}{lcccc}
\hline \multicolumn{1}{c}{ Indep Variable } & $\begin{array}{c}\text { Standard } \\
\text { REM }\end{array}$ & $\begin{array}{c}\text { REM with Cross } \\
\text { Section SUR }\end{array}$ & $\begin{array}{c}\text { REM with White cross- } \\
\text { section SE \& cov }\end{array}$ & $\begin{array}{c}\text { REM with Cross } \\
\text { Section weight }\end{array}$ \\
\hline C & $-31.218^{* *}$ & -31.218 & $-31.218^{*}$ & $-31.218^{* *}$ \\
CPI & -0.2008 & -0.2008 & -0.2008 & -0.2008 \\
UR & $0.1745^{* * *}$ & $-0.1745^{* *}$ & $-0.1745^{* * *}$ & $-0.1745^{*}$ \\
LNGDP & $6.5607^{* * *}$ & $6.5607^{* *}$ & $6.5607 * * *$ & $6.5607^{* * *}$ \\
ICFI & -0.0805 & $-0.0805^{*}$ & $-0.0805^{* * *}$ & $-0.0805^{*}$ \\
TECH & 0.0329 & 0.0329 & $0.0329 *$ & 0.0329 \\
\hline R-squared & & 0.2327 & & \\
Adjust R-squared & & 0.2004 & $*$ sign level of $90 \%$ & \\
F-Stat & & $7.2168 * * *$ & $* *$ sign level of $97.5 \%$ & \\
DW stat & 0.8966 & $* * *$ sign level of $99 \%$ & \\
\hline
\end{tabular}

Last findings will be disclosed here is the role of the development of Islamic finance. From the results of the three models, indicated the influence of the ICFI is significantly towards FII, however it is small but negative. ICFI is the indicator of the development of Islamic finance as measured by six indicators, the percentage of Muslim population (7.3\%), the number of Islamic banks (21.9\%), the share of assets of Islamic finance (13.4\%), the supervisory role of the shariah regime (19.6\%), the size of sukuk $(7.1 \%)$ and education and culture of Islamic 
finance (5.7\%). Therefore, this means that the development of Islamic finance has not much help to add public access to the financial sector.

Table 4. Pearson Correlation coefficient between ICFI and FII indicator

\begin{tabular}{ll}
\hline \multicolumn{1}{c}{ Variables } & \multicolumn{1}{c}{ Corr } \\
\hline number of ATM & $0.3864 * *$ \\
number of Bank Branches & $0.3006^{* *}$ \\
number of Depositors & 0.052 \\
Deposit Outstanding & $0.5129 * *$ \\
Loan Outstanding & $0.2568 * *$ \\
Mobile money & -0.1543 \\
FII & 0.1680 \\
\hline
\end{tabular}

However, it can be seen, through Pearson's correlation coefficient, that there are some positive correlations between ICFI and some financial inclusion indicators such as number of ATM, bank branches, deposit outstanding and loan outstanding. But ICFI does not have significant correlation with number or depositors and mobile money. This finding may relate with the failure of Islamic finance to create their own market segment rather than to compete with existing markets. Also, it could indicate the failure of Islamic finance to take advantage of technological advancement or financial technology. However, it needs more objective research on this field.

Lastly, the model has limitation to explain the reality even though it may produce efficient estimation. As shown from its goodness of fit the model, the model can explain only 23.27 percent of the movement of FII. It means that there many factors which cannot be explained through this model, especially many relevant variables which was omitted from the estimated model.

\section{Conclusion}

On average, Financial Inclusion Index in Islamic banking countries is low compared with the world average. This lower level of financial inclusion may be caused by many factors, either internal or external factors. Based on the limited data and model, this paper finds that macro- economic factors, which level of employment and GDP per capita, have the most significant influences on financial inclusion rather than none economic factors. Other socio non-economic variables such as information technological advancement and corruption level do not significant influence on financial inclusion. However, the development of Islamic finance in those country play an important role on financial inclusion, but small and it has negative association. It indicates that the development of Islamic finance in the corners of the Islamic world have no serious attention to inclusive finance. It is possibly because in general Islamic finance is still in the early growth stage and few of them is on international recognition stage.

Accordingly, it is too mature to claim than Islamic finance is in favour with inclusive finance, especially for the development of Islamic bank and capital market. However, the development of Islamic micro finance and Islamic public finance may help much to achieve inclusive finance, but both have not been linked to the mainstream Islamic finance, which are Islamic banking and capital market. Therefore, in order to increase financial inclusion in IB countries, the authority has to support to strengthen the linkage between Islamic banking and capital market development with micro finance and public economic development.

\section{References}

Ascarya, Rahmawati, S., \& Tanjung, H. (2015). Designing Holistic Financial Inclusion Based on Maqashid Shariah. Inaugural Annual Symposium on Islamic Finance 2015 "Islamic Finance: A Catalyst for Shared Prosperity", Istanbul, Turkey, September 8-9, 2015, (2).

Demirguc-kunt, A., \& Klapper, L. (2013). Measuring Financial Inclusion:Explaining Variation Across and Within Countries. Brookings Papers on Economic Activity, 46(1(Spring)), 279-340.

Demirguc-Kunt, A., Klapper, L., \& Randall, D. (2013). Islamic Finance and Financial Inclusion: Measuring Use of and Demand for Formal Financial Services among Muslim Adults. Policy Research Working Papers, 6642(October), the World Bank, Development Reserch Group, http://doi.org/doi:10.1596/1813-9450-6642 
E. Kempson, C. Whyley, J. Caskey and S. Collard, (2000), "In or out? Financial Exclusion: A Literature and Research Review", Report, Financial Services Authority.

European Commission (2008), Financial Services Provision and Prevention of Financial Exclusion, pp. 48-49

H.M. Treasury (2004), Promoting financial inclusion. H.M. Treasury: London

International Finance Corporation IFC (2014), Global Financial Development Report, Financial Inclusion, International Bank for Reconstruction and Development, The World Bank.

Kainth, Gursharan Singh, (2013), "Developing an Index of Financial Inclusion", Anvesha the journal of Management, Vol. 6 No.2, pp. 1-11.

Kempson E and Collard S, (2014), Developing a Vision for Financial Inclusion, Friend Provident Foundation, Surrey.

Kim, Jim Yong (2014), "Financial Inclusion", Global Financial Development Report, International Finance Corporation, the World Bank, www.worldbank.org

Kodan Anand S. and Kuldip S. Chhikara (2013), "A Theoretical and Quantitative Analysis of Financial Inclusion and Economic Growth", Management and Labour Studies, Vol. 38, pp103

Kumar Nitin, (2013), "Financial Inclusion and its Determinants: Evidence from India", Journal of Financial Economic Policy, Vol. 5, No. 1.

Kunt, Asli Demirguc and Leora Klapper (2013), "Measuring Financial Inclusion Explaining Variation Across and Within Countries", Paper presented at the Spring 2013 Brookings Panel on Economic Activity, March 21-22, 2013

Midgley, J. (2005). Financial inclusion, universal banking and post offices in Britain. Royal Geographical Society, 37(3), 277-285. http://doi.org/10.1111/j.1475-4762.2005.00631.x

Mohieldin, M., Iqbal, Z., Rostom, A., \& Fu, X. (2012). The Role of Islamic Finance in Enhancing Financial Inclusion in Organization of Islamic Cooperation (OIC) Countries. Islamic Economic Studies, 20(2), 55-120. http://doi.org/10.1596/1813-9450-5920

Naceur, S. Ben, Barajas, A., \& Massara, A. (2015). Can Islamic banking increase financial inclusion? IMF Working Paper, 1-41. http://doi.org/10.5089/9781498370813.001

Sharma, Mandira, 2008, "Index of Financial Inclusion," ICRIER Working Paper 215.

Sharma Mandira, 2010, "Index of Financial Inclusion." CITD Discussion Paper 10-05.

Sharma, Mandira, 2012, "Index of Financial Inclusion - A measure of financial sector inclusiveness," Berlin Working Papers on Money, Finance, Trade and Development, Working Paper No. 07/2012.

United Nations, (2007), Press Conference on Best Practice for Financial Inclusion, UN Department of Public Information, 14th September 2007.

Warsame, M. H. (2009). The role of Islamic finance in tackling financial exclusion in the UK. Doctoral Thesis, Durham University. Retrieved from http://etheses.dur.ac.uk/23/

World Bank (2008), Access to finance and development: Theory and measurement. Washington, DC: World Bank. Retrieved from http://webcache.googleusercontent.com/ search?q=cache:RPHTmNKYOhoJ:siteresources.worldbank.org/INTFINFORALL/Resources/ 40995831194373512632/FFA_ch01.pdf $+\& c d=1 \& h l=e n \& c t=c l n k \& g l=$ in

World Bank (2014), Global Financial Development Report 2014: Financial Inclusion. Washington, DC: World Bank. doi:10.1596/978-0-8213-9985-9. License: Creative Commons Attribution CC BY 3.0

Zulkhibri, M. (2016). Financial inclusion, financial inclusion policy and Islamic finance. Macroeconomics and Finance in Emerging Market Economies, 843(July), 1-18. http://doi.org/10.1080/17520843.2016.1173716. 